\title{
Pemanfaatan Biji Chia (Salvia hispanica L.) untuk Meningkatkan Kualitas Susu Diversifikasi
}

\section{Utilization of Chia Seeds (Salvia hispanica L.) for Improve Diversified Milk Quality}

\author{
Rasbawati* dan Irmayani \\ Program Studi Peternakan, Fakultas Pertanian, Peternakan dan Perikanan \\ Universitas Muhammadiyah Parepare - Indonesia \\ *Corresponding E-mail: rasbawati@gmail.com
}

(Diterima: 24 November 2020; Disetujui: 22 Maret 2021)

\begin{abstract}
ABSTRAK
Penelitian ini bertujuan untuk mengetahui kualitas kimia yang meliputi kadar air, kadar protein dan kadar lemak susu pasteurisasi dengan penambahan biji chia (Salvia hispanica L.). Penelitian ini menggunakan metode eksperimental Rancangan Acak Lengkap (RAL) dengan 4 perlakuan dan 3 kali ulangan. Materi penelitian menggunakan susu murni yang diperoleh dari peternakan rakyat dan biji chia (Salvia hispanica L.). Adapun perlakuan yang diterapkan adalah penambahan biji chia sebanyak $0 \%\left(\mathrm{C}_{0}\right)$, 6\% (C1), 8\% (C2), dan 10\% (C3). Komponen parameter yang diamati adalah kadar air, kadar protein dan kadar lemak susu pasteurisasi. Analisis data menggunakan metode analisis ragam (ANOVA) apabila terdapat pengaruh perlakuan, analisis dilanjutkan dengan uji DMRT. Hasil penelitian menunjukkan bahwa penambahan biji chia berpengaruh sangat nyata $(\mathrm{P}<0,01)$ terhadap nilai kadar air, kadar protein dan kadar lemak susu pasteurisasi. Penambahan biji chia (Salvia hispanica) sampai dengan level 10\% menghasilkan kadar air sebesar 79,68\%, kadar protein sebesar 6,23\% dan kadar lemak sebesar 6,33\%. Kesimpulan dari penelitian ini menunjukkan bahwa semakin tinggi level penambahan biji chia maka semakin tinggi pula kadar protein dan kadar lemak yang dihasilkan. Akan tetapi sebaliknya pada nilai kadar air menghasilkan nilai yang semakin rendah. Perlakuan terbaik terdapat pada penambahan biji chia sebesar $10 \%$.
\end{abstract}

Kata kunci: susu pasteurisasi, biji chia, kadar air, kadar protein, kadar lemak

\section{ABSTRACT}

This study aims to determine the chemical quality, including moisture content, protein content, and fat content of pasteurized milk with chia seeds (Salvia hispanica L.). The research used an experimental method with a completely randomized design (CRD) with four treatments and three replications. The research material used pure milk obtained from smallholder farms and chia seeds. The treatments were applied the addition of $0 \%(C 0), 6 \%(C 1), 8 \%(C 2)$, and 10\% (C3) chia seeds. The parameter components were observed water content, protein content, and fat content in pasteurized milk. Data analysis used the analysis of variance (ANOVA) method. If there was an effect of treatment, the analysis was continued with the DMRT test. The results showed that the addition of chia seeds had a very significant effect $(P<0.01)$ on the value of water content, protein content, and fat content of pasteurized milk. The addition of chia up to a level of $10 \%$ resulted in water content of $79.68 \%$, protein content of $6.23 \%$, and fat content of $6.33 \%$. The conclusion of this study shows that the higher the level of chia seed addition, the higher the protein content and fat content produced. However, on the other hand, the water content value results in a lower value. The best treatment was found in the addition of $10 \%$ chia seeds.

Keywords: pasteurized milk, chia seeds, moisture content, protein content, fat content 


\section{PENDAHULUAN}

Susu merupakan cairan berwarna putih yang berasal dari kelenjar susu (ambing) ternak perah yang sehat yang diperah sesuai dengan prosedur yang telah ditentukan (Meutia et al., 2016). Dapat didefinisikan bahwa susu merupakan bahan pangan asal hewani yang sangat baik untuk dikonsumsi oleh manusia. Hal ini disebabkan susu memiliki hampir seluruh zat-zat gizi yang dibutuhkan oleh tubuh mahluk hidup. Zat yang terkandung di dalam susu memiliki komposisi yang lengkap, mudah dicerna dan diserap (Fitasari et al., 2018). Anjarsari (2020) menyatakan bahwa komposisi kimia yang terkandung dalam susu diantaranya air $87,25 \%$, lemak $3,8 \%$, protein $3,2 \%$, laktosa $4,7 \%$, abu $0,85 \%$ dan bahan kering $12,75 \%$. Tingginya zat nutrisi yang terkandung pada susu memberi peluang yang optimal bagi pertumbuhan mikroba seperti bakteri, kamir, dan kapang, hal ini disebabkan karena mikroba membutuhkan bahan makanan dalam proses pertumbuhannya.. Pertumbuhan berbagai mikroba tersebut akan mengubah kualitas mutu susu yang dicirikan dengan berubahnya warna, tekstur dan aroma. Sehingga dalam waktu yang sangat singkat susu menjadi tidak layak untuk dikonsumsi bila tidak ditangani secara baik dan tepat (Saleh, 2004). Salah satu upaya yang dapat dilakukan untuk penanganan susu segar yaitu pasteurisasi (pemanasan) dimana perlakuan ini bertujuan membunuh bakteri patogen di dalam susu. Perlakuan panas (pasteurisasi) adalah teknologi pemprosesan yang paling banyak digunakan dalam industri susu. Tujuan utamanya adalah memusnahkan mikroorganisme, baik patogen maupun pembusukan, untuk memastikan susu aman dan memiliki masa simpan yang lama (Bezie, 2019).

Susu pasteurisasi menurut Standar Nasional Indonesia (SNI) Nomor 01-39511995 merupakan susu segar, susu rekombinasi dan susu rekonstitusi yang mengalami proses pemanasan pada temperatur $63-66^{\circ} \mathrm{C}$ dengan waktu minimum 30 menit atau pada pemanasan dengan temperatur $72^{\circ} \mathrm{C}$ selama waktu minimum 15 detik, kemudian segera diturunkan suhunya sampai $10^{\circ} \mathrm{C}$, selanjutnya diolah dan dikemas secara steril dan disimpan pada suhu maksimum $4,4^{\circ} \mathrm{C}$. Untuk meningkatkan kandungan nilai nutrisi susu pasteurisasi, maka dilakukan fortifikasi dari bahan pangan yang memiliki kandungan nutrisi yang tinggi, salah satu diantaranya adalah biji chia (Salvia hispanica L.)

Biji chia atau lebih dikenal dengan sebutan chia seed (Salvia hispanica L.) merupakan salah satu bahan alami yang berpotensi sebagai alternatif pengembangan produk pangan fungsional dan memiliki dampak kesehatan yang positif (Safari et al, 2018). Menurut Kusnandar et al. (2020) tanaman ini berasal dari Amerika Latin khususnya Guatemala dan Meksiko. Tanaman ini dapat tumbuh di daerah memiliki iklim tropis dan subtropis (Uzunova et al., 2019). Biji chia memiliki ciri-ciri bentuk yang kecil, oval dan pipih dengan ukuran panjang antara $2-2,5 \mathrm{~mm}$, lebar $1,2-1,5 \mathrm{~mm}$ dan ketebalan 0,8 - $1 \mathrm{~mm}$ (Ixtaina et al., 2008). Warna biji chia bervariasi dari hitam, abu-abu, atau hitam berbintik hingga putih (Hrnčič et al., 2019). Kandungan kimia biji chia terdiri atas karbohidrat (26-41\%), lemak (30-33\%), protein $(15-25 \%)$, mineral $4-5 \%$ ) dan serat (18-30 \%) (Ixtaina et al., 2008). USDA (2011) melaporkan bahwa biji chia mengandung asam lemak omega 3 (asam linolenat) sebesar $17,83 \%$. Kandungan lemak pada biji chia cukup tinggi (30-40\% dari berat biji), dan hampir $60 \%$ dari total lemak berupa asam $\alpha$-linolenat (omega 3). Selain itu, biji chia juga mengandung serat pangan (lebih dari 30 $\%$ dari total berat) dan sebanyak 5-6\% gum yang terkandung pada biji chia juga dapat berfungsi sebagai serat pangan (Reyes et al., 2008).

Salah satu karakteristik fisik yang khas dimiliki biji chia adalah kemampuannya untuk membentuk lapisan gel, lapisan gel ini terbentuk setelah biji terhidrasi oleh air. Pada saat kontak dengan air, bagian luar epidermis biji pecah dan mengeluarkan filament gum 
yang segera menyerap air dan membentuk lapisan gel yang tampak seperti kapsul transparan (Hernandez, 2012).

Selain memiliki karakteristik fisik yang khas, biji chia juga dilaporkan memiliki manfaat bagi kesehatan. Biji chia merupakan sumber asam lemak $\alpha$ - linolenat (Omega-3), serat pangan, protein dengan nilai biologis tinggi, serta antioksidan (Craig, 2004). Beberapa penelitian mengenai fungsionalitas biji chia terhadap kesehatan juga telah dilakukan. Dalam penelitian yang dilakukan oleh Ayerza (2007), melaporkan bahwa biji chia dapat menurunkan dan menstabilkan kadar kolesterol darah. Selain itu, konsumsi biji chia juga dilaporkan memiliki efek untuk menurunkan berat badan pada penderita obesitas (Brissette, 2013). Disamping penggunaannya dalam bidang kesehatan, biji chia seed juga digunakan dalam industri pengolahan pangan yaitu sebagai suplemen minyak sehat pada formulasi kue (Borneo et al., 2010), biskuit (Barrientos et al., 2012), pasta (Oliviera et al., 2015), yoghurt (Attalla and El-Hussieny, 2017), selai nanas (Nduko et al., 2018) dan pada pembuatan roti gandum (Romankiewicz et al., 2017).

Hasil penelitian yang dilakukan oleh Atalla dan El-Hussieny (2017) melaporkan bahwa penambahan 3\% biji chia pada produk yoghurt mousse menghasilkan kadar protein dan kadar lemak yang tinggi. Selain itu, Faid (2017) dalam penelitiannya juga melaporkan fortifikasi biji chia $(3 \%, 6 \%, 9 \%$ dan $12 \%)$ memberikan hasil terbaik terhadap sifat fisik, sensoris dan fisikokimia produk yoghurt dan keju lunak.

Berdasarkan uraian yang telah dipaparkan di atas, penelitian ini dirancang untuk mengetahui pengaruh penambahan biji chia (Salvia hispanica) terhadap kadar air, kadar protein dan kadar lemak susu pasteurisasi.

\section{METODE}

\section{Materi}

Materi pada penelitian ini terdiri atas bahan dan alat, adapun bahan yang digunakan antara lain adalah susu murni yang diperoleh dari peternakan sapi perah yang berasal dari Kabupaten Enrekang, biji chia yang diperoleh secara komersil, aquades, $\mathrm{H}_{2} \mathrm{SO}_{4} \mathrm{NaOH}, \mathrm{HCl}$ $0,1 \mathrm{~N}, \mathrm{H}_{3} \mathrm{BO}_{3} 4 \%$,selenium, alkohol, tissue, kertas label, glove dan air.

Peralatan yang digunakan meliputi gelas ukur, labu ukur, kompor, panci, thermometer, pengaduk, tabung butyrometer, timbangan digital, timbangan analitik, Bunsen, wadah plastik, tabung reaksi, plastik klip, spektrofotometer, botol pengemas, erlenmeyer, pipet tetes, pipet ukur, waterbath, seperangkat alat destruksi, labu kjeldahl, oven, cawan, autodestilasi dan kain kasa.

\section{Prosedur Penelitian}

Prosedur yang diterapkan pada penelitian ini memiliki 2 tahapan, yaitu:

1. Pembuatan bubuk biji chia

Biji chia sebanyak 300 g dihaluskan dengan menggunakan blender dan disimpan pada plastik klip.

2. Pembuatan susu pasterisasi dengan penambahan biji chia

Sebanyak 4 L susu sapi segar yang diperoleh dari peternakan rakyat dipanaskan dengan metode konvensional atau metode holding yaitu pemanasan dengan menggunakan suhu $60^{\circ} \mathrm{C}$ selama 30 menit. Kemudian susu ditambahkan dengan biji chia seed sesuai dengan perlakuan $\mathrm{C}_{0}$ (kontrol) $\mathrm{C} 1$ (6\%), C2(8\%) dan C3 (10\%). Masing-masing perlakuan membutuhkan 1 L susu.

\section{Pengukuran Susu Diversifikasi}

\section{Kadar Air}

Analisis kadar air sampel susu pasteurisasi dilakukan dengan cara pengeringan (Sudarmadji, 2010). Adapun prosedur kerja pengukuran kadar air susu yaitu mengeringkan di dalam oven selama 
15 menit cawan kosong beserta tutupnya. Setelah menghomogenkan sampel ditimbang sebanyak $5 \mathrm{~g}$, selanjutnya memasukkan sampel ke dalam oven dan dikeringkan selama 3 jam, setelah itu mendinginkan cawan selama 3-5 menit, setelah dingin menimbang sampel kemudian mengeringkan kembali ke dalam oven selama 30 menit sampai diperoleh berat yang tetap. Tahap selanjutnya yaitu mendinginkan sampel hingga diperoleh berat yang konstan dan menghitung kadar air susu dengan rumus:

$\%$ Kadar air $=\frac{\text { Berat awal }- \text { Berat } \text { Akhir }}{\text { Berat Sampel }} \times 100 \%$

\section{Kadar Protein}

Penentuan kadar protein susu pasteurisasi dengan penambahan biji chia diterapkan dengan metode Kjeldahl (Yenrina, 2015). prosedur kerja penentuan kadar protein pertama-tama yaitu menimbang $1 \mathrm{~g}$ sampel susu dan memasukkan ke dalam labu Kjeldahl, menambahkan $25 \mathrm{ml} \mathrm{H}_{2} \mathrm{SO}_{4}$ dan $1 \mathrm{~g}$ selenium pekat kedalam labu kjeldahl. Mendekstruksi di dalam lemari asam hingga larutan berwarna jernih selama 30 menit pada suhu $375^{\circ} \mathrm{C}$. Kemudian mendinginkan hasil destruksi dan memasukkan sampel kedalam labu ukur $100 \mathrm{ml}$ dan diencerkan dengan aquades sampai batas tanda lalu dihomogenkan. Tahap selanjutnya adalah memipet larutan tersebut sebanyak $25 \mathrm{ml}$ dan dan menambahkan $50 \mathrm{ml}$ $\mathrm{NaOH} 40 \%$ kemudian didestilasi. Tahapan selanjutnya adalah menampung hasil destilat ke dalam Erlenmeyer yang berisi 3 tetes indikator mix dan $25 \mathrm{ml} \mathrm{H}_{3} \mathrm{BO}_{3} 4 \%$. Hasil destilasi kemudian dititrasi dengan asam sulfat $0,1 \mathrm{~N}$ sampai larutan berubah dari hijau menjadi ungu. Tahap terakhir yaitu menghitung kadar protein sampel dengan menggunakan rumus sebagai berikut:

$$
\% \text { Protein }=\% \mathrm{~N} \mathrm{x} \text { faktor konversi }
$$

Keterangan:

Faktor konversi $=6,38$ (besarnya faktor konversi pada susu dan produk susu)

\section{Kadar Lemak}

Untuk penentuan kadar lemak dalam penelitian ini, prosedur yang diterapkan yaitu metode Gerber. Adapun prosedur kerjanya yaitu pertama-tama mengisi butyrometer masing-masing sebanyak $10 \mathrm{ml} \quad \mathrm{H}_{2} \mathrm{SO}_{4}$ melalui dinding tabung dan memasukkan 10 $\mathrm{ml}$ sampel susu. Kemudian, menambahkan $1 \mathrm{ml}$ alkohol ke dalam butyrometer dan menyumbatnya dengan penyumbat karet yang diputar dengan erat dan menghomogenkan selama 3-5 menit. Setelah itu memasukkan butyrometer ke dalam waterbath selama 3-5 menit dengan suhu $57-65^{\circ} \mathrm{C}$. Tahap selanjutnya adalah menyentrifus dengan kecepatan 1200 rpm (1200 kali putaran per menit) selama 5 menit. Setelah itu, memasukkan butyrometer kembali ke dalam waterbath selama 3-5 menit, kemudian membersihkan dan mengeringkan lalu membaca skala yang tertera (Legowo et al., 2005).

\section{Rancangan Penelitian}

Rancangan yang diaplikasikan pada penelitian ini adalah Rancangan Acak Lengkap (RAL) dengan 4 taraf perlakuan dan 3 ulangan. Perlakuan meliputi $\mathrm{C}_{0}(0 \%), \mathrm{C} 1$ (6\%), C2 (8\%) dan C3 (10\%). Variabel yang diamati adalah kadar air, kadar protein dan kadar lemak susu pasteurisasi.

\section{Analisis Data}

Analisis data pada penelitian ini menggunakan analisis ragam (Analysis of Variant) apabila perlakuan ada yang berpengaruh maka analisis dilanjutkan dengan uji DMRT. Data penelitian dianalisis dengan SPSS versi 16 for windows pada taraf signifikan $1 \%$.

\section{HASIL DAN PEMBAHASAN}

\section{Kadar Air Susu Diversifikasi}

Rerata nilai kadar air yang diperoleh pada penelitian ini disajikan pada Gambar 1. Berdasarkan hasil analisis ragam menunjukkan bahwa penambahan biji chia dengan level yang berbeda memberikan 


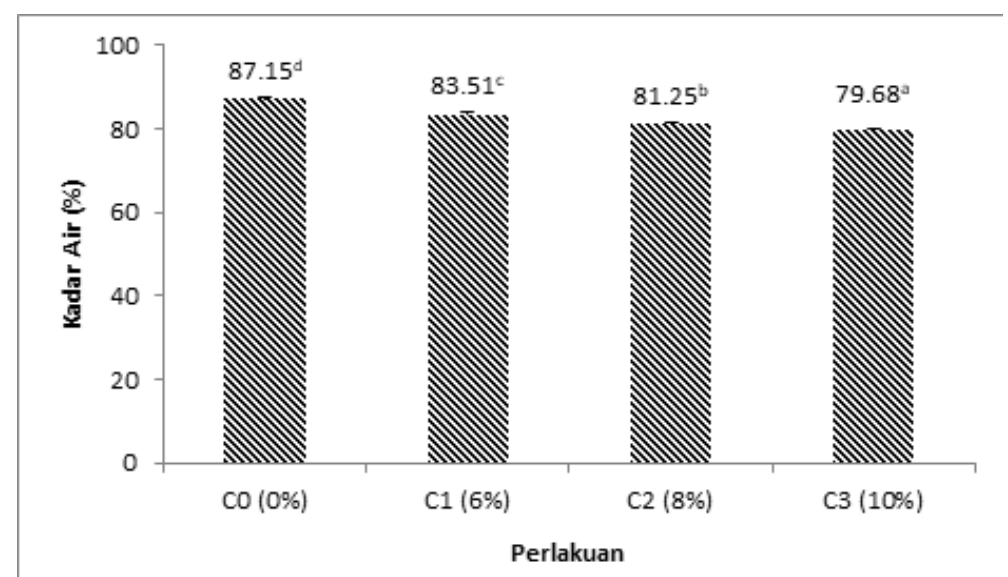

Gambar 1. Rata-rata nilai kadar air susu pasteurisasi dengan penambahan biji chia dengan level yang berbeda.

pengaruh sangat nyata $(\mathrm{P} 0,01)$ terhadap kadar air susu pasteurisasi. Setelah diuji lanjut diperoleh hasil bahwa perlakuan $\mathrm{C} 0$ berbeda nyata dengan perlakuan $\mathrm{C} 1, \mathrm{C} 2$ dan C3. Adapun Kadar air tertinggi diperoleh pada perlakuan C0 (Kontrol) yaitu 87,15\%, sedangkan kadar air terendah diperoleh pada perlakuan C3 (10\%) yaitu 79,68\%.

Kadar air pada susu pasteurisasi dengan penambahan biji chia seed semakin menurun seiring dengan meningkatnya level biji chia yang ditambahkan, hal ini disebabkan karena biji chia memiliki kemampuan dalam menyerap air dan akan membentuk gum (gel) sehingga semakin tinggi persentase penambahan biji chia maka semakin banyak pula air yang diserap. Hal ini sesuai dengan pernyataan Safari et al. (2016) bahwa karakteristik fisik khas dari biji chia seed adalah kemampuannya dalam membentuk lapisan gum seperti kapsul yang berasal dari komponen gum tersebut. Lapisan mirip kapsul ini terbentuk setelah biji terhidrasi dengan air. Lapisan kapsul gum ini mampu menahan dan menyerap air hingga beberapa kali berat keringnya.Fenomena penyerapan air oleh biji chia, khususnya filamen gum karena diduga gum biji chia merupakan polisakarida anionic dengan gugus fungsional berupa hidroksil dan karboksilat (Campos et al., 2014).

Kemampuan menyerap air yang dimiliki oleh biji chia mempengaruhi viskositas larutan dan dalam konsentrasi yang tinggi dapat menyebabkan pembentukan gel. Mekanisme terbentuknya gum terjadi pada saat biji chia terhidrasi oleh air, gum terbentuk di sekeliling biji chia, hal ini disebabkan karena gum terletak di sel luar (outer cell) dari selubung biji (seed coat) atau testa yang juga disebut dengan sel mucilaginous (Windsor et al., 2000). Kulczynsky et al. (2019) menyatakan bahwa gum biji chia merupakan serat pangan larut air yang dapat mengembang dan membentuk gel ketika kontak dengan air serta memberikan larutan yang kental, peningkatan ketebalan kapsul dan daya serap air biji chia menyebabkan peningkatan viskositas larutan.

\section{Kadar Protein Susu Diversifikasi}

Berdasarkan hasil analisis statistik menunjukkan bahwa penambahan biji chia dengan level yang berbeda memberikan pengaruh sangat nyata $(\mathrm{P}<0,01)$ terhadap kadar protein susu pasteurisasi. Rerata kadar protein susu pasteurisasi dengan penambahan biji chia dapat dilihat pada Gambar 2. Dari hasil uji lanjut diperoleh bahwa perlakuan $\mathrm{C} 0$ berbeda nyata dengan perlakuan $\mathrm{C} 1, \mathrm{C} 2$ dan C3. Rata-rata nilai kadar protein yaitu $3,74 \%$, $4,52 \%, 5,45 \%$ dan $6.23 \%$. Kadar protein terendah terdapat pada perlakuan C0 (tanpa penambahan biji chia dan tertinggi pada 


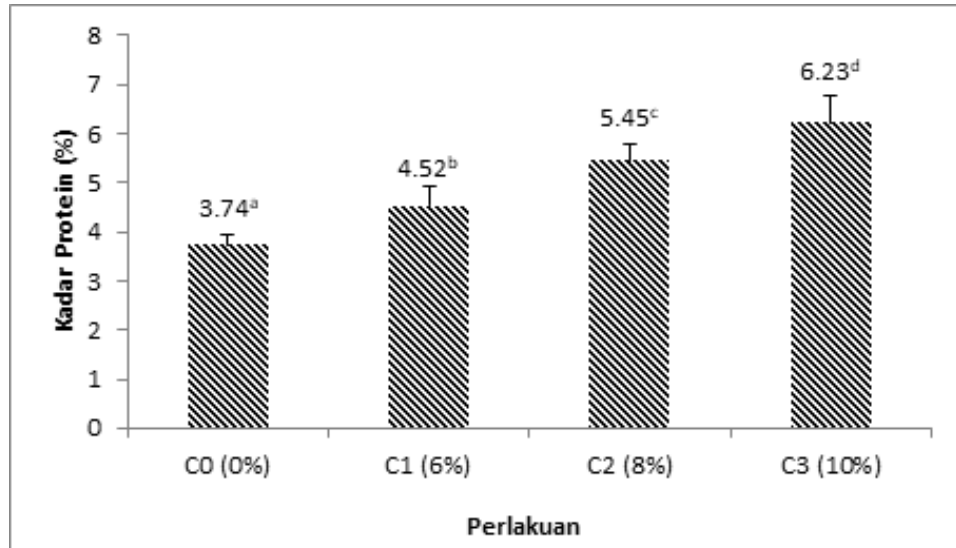

Gambar 2. Rata-rata nilai kadar protein susu pasteurisasi dengan penambahan biji chia (Salvia hispanica) pada level yang berbeda.

perlakuan C3 (penambahan biji chia 10\%).

Dari hasil penelitian diketahui bahwa terjadi kecenderungan peningkatan kadar protein pada tiap perlakuan, kadar protein susu pasteurisasi berbanding lurus dengan penambahan level biji chia dengan kata lain semakin tinggi persentase penambahan biji chia maka semakin tinggi pula kadar proteinnya.Fernandezetal.(2006)melaporkan bahwa dalam biji chia mengandung protein dengan jumlah yang cukup tinggi apabila dibandingkan dengan kadar protein pada biji-bijian lainnya dan bebas dari protein gluten. Menurut USDA (2011) dalam $100 \mathrm{~g}$ biji chia terdapat $16,54 \mathrm{~g}$ protein. Sedangkan pada gum biji chia mengandung kadar protein $4,43 \%$. Pada penelitian ini perlakuan tanpa penambahan biji chia seed diperoleh kadar protein sebesar $3,74 \%$ dimana kadar ini lebih tinggi dari syarat mutu susu pasteurisasi oleh SNI 01-3951-1995 (BSN 1995), yaitu $2,5 \%$ untuk susu pasteurisasi tanpa cita rasa. Penambahan biji chia seed $6 \%, 8 \%$ dan $10 \%$ dapat meningkatkan nilai kadar protein. Hal ini sesuai pernyataan Campoz et al. (2014) yang melaporkan bahwa biji chia seed memiliki kandungan gizi yang baik terutama kandungan protein, lemak dan karbohidrat. Sejalan dengan hal tersebut Romankiewicz et al. (2017) dalam penelitiannya menggunakan biji chia seed ke dalam roti gandum menghasilkan protein
2 kali lebih tinggi. Hal ini mengindikasikan potensi yang baik dari biji chia diaplikasikan di industri pangan. contohnya susu. Ixtaina et al. (2008) melaporkan pula bahwa gum biji chia merupakan kelompok polisakarida anionik. Gum pada biji chia memiliki kandungan gugus karbonil karboksilat dan gugus hidroksil, dengan gugus anionik tersebut, biji chia dapat dikembangkan pada pangan yang mengandung protein tinggi, yang mampu mencegah pengendapan protein akibat titik isoelektrik, yang disebabkan karena bergabungnya gugus karboksil pada gum biji chia dengan gugus muatan positif dari protein.

\section{Kadar Lemak Susu Diversifikasi}

Berdasarkan hasil uji statistik menunjukkan bahwa penambahan biji chia dengan level yang berbeda memberikan pengaruh sangat nyata $(\mathrm{P}<0,01)$ terhadap kadar lemak susu pasteurisasi. Rata-rata kadar lemak susu pasteurisasi dengan penambahan biji chia secara berurut $(\mathrm{C} 0, \mathrm{C} 1, \mathrm{C} 2$ dan C3) yaitu 4,69\%, 5,77\%, 5,70\% dan 6,33\% (Gambar 3). Terdapat perbedaan yang nyata diantara perlakuan setelah dilakukan uji lanjut, perlakuan $\mathrm{C} 0$ berbeda nyata dengan perlakuan $\mathrm{C} 1, \mathrm{C} 2$ dan $\mathrm{C} 3$, perlakuan $\mathrm{C} 1$ berbeda nyata dengan perlakuan $\mathrm{C} 3$ tetapi tidak berbeda nyata dengan perlakuan C2. Dari data yang diperoleh nilai kadar lemak terendah yaitu perlakuan tanpa penambahan biji chia $(0 \%)$ 


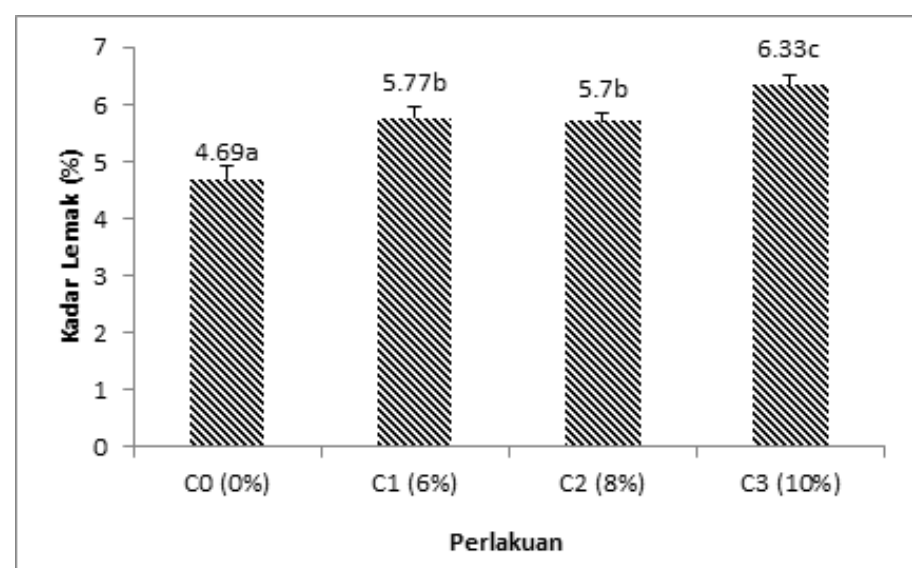

Gambar 3. Rata-rata nilai kadar lemak susu pasteurisasi dengan penambahan biji chia (Salvia hispanica) dengan level yang berbeda.

sedangkan perlakuan dengan nilai kadar lemak tertinggi yaitu pada perlakuan penambahan biji chia sebanyak $10 \%$. Nilai kadar lemak pada penelitian ini lebih tinggi dari Standar Nasional Indonesia (SNI 01-3951-1995) yaitu 2,80\% dengan jenis susu pasteurisasi tanpa penyedap cita rasa. Biji chia dalam penelitian ini diduga berperan penting dalam meningkatkan kadar lemak susu pasteurisasi. Hal ini sejalan dengan pernyataan Ali et al. (2012) bahwa biji chia mengandung asam lemak esensial. Dimana asam lemak esensial merupakan komponen pokok penyusun lemak, asam lemak esensial merupakan jenis asam lemak yang sangat dibutuhkan oleh tubuh namun tidak dapat diproduksi oleh tubuh itu sendiri (Sunur, 2019). Ali et al. (2012) dalam hasil penelitiannya menggunakan hewan coba dengan tujuan membandingkan penggunaan biji rami, rapeseed, dan biji chia sebagai pakan ayam, dari hasil penelitian diketahui bahwa ayam dengan pemberian pakan biji chia memiliki telur dengan kandungan asam linolenat (ALA) lebih tinggi apabila dibandingkan dengan ayam yang diberi pakan rapeseed maupun biji rami. Penelitian lain juga telah dilakukan oleh Ayerza and Coates (2007) dengan menggunakan biji chia pada ransum hewan percobaan babi dan kelinci dari hasil penelitian menunjukkan bahwa asam lemak PUFA pada lemak daging mengalami peningkatan dan juga pada kualitas organoleptik aroma dan rasanya. Penelitian dengan menggunakan biji chia juga berdampak positif pada uji klinis terhadap manusia (Nieman et al., 2009; Jin et al., 2010 dan Martha et al., 2012).

\section{KESIMPULAN}

Berdasarkan hasil penelitian penambahan biji chia (Salvia hispanica L) pada level yang berbeda dapat meningkatkan nilai gizi (kadar protein dan kadar lemak) namun menurunkan kadar air susu diversifikasi. Perlakuan terbaik diperoleh pada penambahan biji chia sebesar 10\%. Diharapkan pada penelitian selanjutnya dapat menilai kualitas sensorik (nilai organoleptik) untuk mengukur daya terima produk oleh konsumen.

\section{UCAPAN TERIMA KASIH}

Ucapan terima kasih penulis haturkan kepada Majelis Diktilitbang Muhammadiyah atas biaya penelitian pada skim riset $\mathrm{MU}$ Batch IV Tahun Anggaran 2020.

\section{DAFTAR PUSTAKA}

Ali, N.M., S.K. Yeap, W.Y. Ho, B.K. Beh, S.W. Tan, and S.G. Tan. 2012. The promising future of chia, Salvia hispanica L. J. of 
Biomedicine and Biotechnology.

Anjarsari, B. 2010. Pangan Hewani. Graha Ilmu, Yogyakarta.

Attalla, N. R. and E.A. El-Hussieny. 2017. Characteristics of nutraceutical yoghurt mousse fortified with chia seeds. Int.J. of Environment, Agriculture and Biotechnology, 2(4): 2033-2046.

Ayerza, R. and W. Coates. 2007. Effect of Dietary $\alpha$-Linolenic Fatty Acid Derived From Chia When Fed as Ground Seed, Whole Seed and Oil on Lipid Content and Fatty Acid Composition of Rat Plasma. Annals of Nutrition and Metabolism. 51(1): 27-34.

Badan Standardisasi Nasional (BSN). 1995. SNI 01-3951-1995 tentang Susu Pasteurisasi. Jakarta.

Barrientos, V. A., A. Aguirre, and R. Borneo. 2012. "Chia (Salvia hispanica L.) can be used to manufacture sugar-snap cookies with an improved nutritional value," International Journal of Fuzzy Systems, 1: 135-143.

Bezie, A. 2019. The Effect of Different Heat Treatment on the Nutritional Value of Milk and Milk Products and Shelf-Life of Milk Products. A Review. 2019. Dairy and Vet Sci J. 2019; 11(5).

Borneo, R., A. Aguirre. and A. E. Leon. 2010. Chia (Salvia hispanica L.) gel can be used as egg or oil replacer in cake formulations. Journal of the American Dietetic Association. 110(6): 946-949.

Brissette, C. 2013. The Effect of Salvia hispanica L. Seeds on Weight Loss in Overweight and Obese Individuals with Type 2 Diabetes Mellitus. University of Toronto. Department of Nutritional Sciences.

Campos, M.R., N.C. Solis, G.R. Rubio, L.C. Guerrero, and D. B. Ancona. 2014. Chemical and Functional Properties of Chia Seed (Salvia hispanica L.) Gum. Mexico International journal of Food Science.
Craig, R. 2004. Application for approval of whole chia (Salvia hispanica L.) seed and ground whole seed as novel food ingredient. Northern Ireland, Company Representative. Mr D Amstrong.

Faid, S.M.A.E.F. 2017. Evaluation of yoghurt and soft cheese fortified with chia seed. World Journal of Dairy \& Food Sciences 12 (1): 01-12.

Fernández, I., R. Ayerza, W. Coates, S.M. Vidueiros, N. Slobodianik, and A.N. Pallaro. 2006. Nutritional Characteristics of Chia. Actualizacion en Nutricion. 7: 23-25.

Fitasari, P. Syahir, M. dan Mustarin, A. 2018. Diversifikasi produk susu pasteurisasi dengan penambahan sari buah jambu biji merah (Psidium gujava Linn). Jurnal Pendidikan Teknologi Pertanian. 4(Supl): S69- S75

Hernandez, L.M. 2012. Gum Form Chia Seeds (Salvia hispanica): Microstructure, Physico- Chemical Characterization and Application in Food In Food Industry. $\mathrm{PhD}$ Thesis at Pontficia Universidad Catolica de Chile, 120h.

Hrnčič. M. K., M. Ivanovski, Cör and Ž. Knez. 2019. Chia Seeds (Salvia hispanica L.): An Overview-Phytochemical Profile, Isolation Methods, and Application. Molecules 2020, 25: 11.

Ixtaina, V.Y., S. M. Nolasco, and M. C. Tomas. 2008. Physical properties of chia (Salvia hispanica L.) seeds. Industrial Crops and Products, 28(3): 286-293.

Jin, F., D.C. Nieman, W. Sha, G. Xie, Y. Qiu, and W. Jiaose. 2010. Supplementation of milled chia seeds increases plasma ALA and EPA in postmenopausal women. Plant Foods For Human Nutrition. 67: 105-110.

Kulczynsky, B., Cisowska, J. K., Taczanowski, M., Kmiecik, D. and Michalowska, A. G. 2019. The chemical composition and nutritional value of chia seed: Current state of knowledge. Nutrients 
11(6): 1-16.

Kusnandar. F., A. Safari. dan E. Syamsir. 2020. Perubahan karakteristik fisik model minuman biji chia akibat proses pemanasan, perubahan $\mathrm{pH}$, dan penambahan gula dan garam. Jurnal Mutu Pangan. 7(1): 21-29.

Legowo, A. M., Nurwantoro dan Sutaryo. 2005. Analisis Pangan. Badan Penerbit Universitas Diponegoro, Semarang.

Oliveira, M. R., M. E. Novack, C. P. Santos, E. Kubota, and C. S. Da Rosa. 2015. Evaluation of replacing wheat flour with chia flour (Salvia hispanica L.) in pasta. emina: Ci'encias Agr'arias, 36(4): 2545-2553.

Martha, G.C., R.T. Armando, and A.A. Carlos. 2012. A dietary pattern including Nopal, Chia seed, soy protein, and oat reduces serum triglycerides and glucose intolenace in patients with metabolic syndrome. Journal of Nutrition. 142(1): 64-69.

Meutia, N., Rizalsyah, T., Ridha, S. dan Sari, M.K. 2016. Residu Antibotika Dalam Air Susu Segar Yang Berasal Dari Peternakan Di Wilayah Aceh Besar. Jurnal Ilmu Ternak. 16(21).

Nduko. J. M., R. W. Maina, R. K. Muchina, and S. K. Kibitok. 2018. Application of chia (Salvia hispanica) seeds as a functional component in the fortification of pineapple jam. Food Sci Nutr. 2018(6): 2344-2349.

Nieman, D.C.,E.J. Cayea, M.D. Austin, D.A. Henson, S.R.McAnult, and F. Jin. 2009. Chia seed does not promote weight loss or alter disease risk factors in overweight adults. Nutrition Research. 29(6): 414-418.

Reyes, C. E., A. Tecante A., and M.A.L. Valdivia. 2008. Dietary fiber content and antioxidant activity phenolic compounds present in Mexican chia
(Salvia hispanica L.) seeds.Food Chemistry, 107(2): 656-663.

Romankiewicz, D., W. H. Hassoon., G. C. Pietrzak., M. Sobczyk., M. W. Wojdyla., A. Ceglinska, and D. Dziki. 2017. The effect of chia seed (Salvia hispanica) addition on quality and nutritional value of wheat bread. Hindawi J. Food Qual 7352631: 1-7

Safari, A., F. Kusnandar, dan E. Syamsir. 2016. Biji Chia: Karakteristik Gum dan Potensi Kesehatannya Chia Seeds: Mucilage Characteristic and Its Health Potential. Pangan, 25(2): 137 - 146.

Saleh, E. 2004. Dasar Pengolahan \& Hasil Ikutan Ternak.Fakultas pertanian, Universitas Sumetera Utara. Sumatera Utara.

Sudarmadji, S. 2010. Prosedur Analisa Untuk Bahan Makanan dan Pertanian. Penerbit Liberty, Yogyakarta.

Sunur. I. C. 2019. Mengenal Asam Lemak Esensial. https://www.alodokter. com/mengenal-asam-lemak-esensial (Diakses 10 November 2020).

USDA. 2011. USDA National Nutrient Database for Standard Reference, Release 24. USDA.

Uzunova, G., M. Perifanova-Nemska., Zh. Petkova., St. Minkova, and Kr. Nikolova. 2019. Physicochemical characteristic of chia seed oil from Peru. Bulgarian Chemical Communications, 51(Spec.Iss.D): $217-220$.

Windsor, J.B., V.V. Symonds, J. Mendenhall, and A.M. Lloyd. 2000. Arabidopsis seed coat development: morphological differentiation of the outer integument. The Plant Journal. 22(6): 483-493.

Yenrina, R. 2015. Metode Analisis Bahan Pangan dan Komponen Bioaktif. Andalas University Press. Padang 